\title{
MANUFACTURED FACTUAL INDETERMINACY AND THE GLOBALISATION OF TAX JURISPRUDENCE
}

\author{
Bret $N$ Bogenschneider
}

\begin{abstract}
In this article the 'manufactured' factual indeterminacy now ubiquitous within the practice of international taxation is presented as a result of intersecting global approaches to the theory of law. It is argued that tax law practice assumes a mixture of the theoretical positions averred by Hans Kelsen, Karl Llewellyn, and Ronald Dworkin. To combat the problems raised by this, a 'Soft Realism' approach is proposed in the application of tax heuristics to deal with cases of factual indeterminacy. Drawing some implications from this analysis, the debate over general anti-avoidance rules and complex tax avoidance strategies (eg 'treaty-shopping' and 'double non-taxation') is oriented within the overall framework of tax jurisprudence. Finally, it is argued that the globalisation of tax jurisprudence has enabled accounting firms to actively spread manufactured factual indeterminacy around the world, corrupting the purpose of the law in part by exploiting the weaknesses of formalistic legal interpretation.
\end{abstract}

\section{A. INTRODUCTION}

This article explores the growing problem of 'manufactured' factual indeterminacy within the field of international taxation and its connection to legal methodology. ${ }^{1}$ Such manufactured factual indeterminacy represents an aspect of Oliver Wendell Holmes' 'bad man' problem where multinational firms are able to engage in tax planning to intentionally create factual indeterminacy and thereby benefit from formalistic interpretation of tax laws. ${ }^{2}$ This subset of legal indeterminacy is often observed in the context of tax treaty interpretation and related tax planning by multinational firms. ${ }^{3}$ This article avers that an evolving set of tax heuristics, or what Karl Llewellyn referred to as 'shared professional norms', represents a viable means to counteract such 'manufactured' factual indeterminacy. ${ }^{4}$

\footnotetext{
${ }^{*} \mathrm{PhD}$ (cand), Doctorate International Business Taxation (DIBT) program at Vienna University of Economics and Business; Juris Doctor, Univ of Pennsylvania Law School; LLM in Taxation, Temple Law School. Special thanks to the following: Alex Green (University College London); Michael Potacs; Christoph Bezemek; Austrian Science Fund.

${ }^{1}$ See OECD, 'Base Erosion and Profit Shifting' OECD's Work on Tax Planning (September 2014) ('Base erosion and profit shifting (BEPS) refers to tax planning strategies that exploit gaps in the architecture of the international tax system to artificially shift profits to places where there is little or no economic activity or taxation.') <www.oecd.org/tax/aggressive> accessed 18 August 2015.

2 See Oliver Wendell Holmes, 'The Path of the Law' (1897) 10 Harvard Law Review 457 ('[I]f we take view of our friend the bad man we shall find that he does not care two straws for the axioms or deductions, but that he does want to know what the Massachusetts or English courts likely to do in fact. I am much of this mind. The prophecies of what the courts will do in fact, and nothing more pretentious, are what I mean by the law.').

${ }^{3}$ See OECD, 'BEPS Action 6 Prevent Treaty Abuse' <www.oecd.org/ctp/treaties/> accessed 18 August 2015.

${ }^{4}$ Karl Llewellyn, The Common Law Tradition: Deciding Appeals (Little Brown and Co 1960); Dennis M Patterson, 'Law's Pragmatism: Law as Practice and Narrative' (1990) 76 Virginia Law Review 937; see also Bret N Bogenschneider, 'Wittgenstein on Why Tax Law is Comprehensible' [2015] British Tax Review 252; see also
} 
Factual indeterminacy in tax law is distinguishable from general legal indeterminacy. Indeterminate fact patterns often arise where a finding of a separate body of law, such as corporate law, is be taken as a matter of fact for the application of tax law. Such situations are ubiquitous to tax practice and continuously arise in new and differing forms. An example is Original Issue Discount (OID) where a bond is issued at a discount to par value, which creates factual indeterminacy as to the characterisation of such a discount as either interest income or capital gains (each with differing tax consequences). ${ }^{5}$ Other frequent examples as a matter of international taxation include hybrid debt/equity arrangements, ${ }^{6}$ transfer pricing of intangibles, ${ }^{7}$ and hybrid entity mismatches. ${ }^{8}$

The first step is the orientation of the tax-specific phenomenon of 'factual indeterminacy' within the context of general legal methodology. Accordingly, a comparative descriptive analysis of the methods of Hans Kelsen, Ronald Dworkin and Karl Llewellyn is provided in the context of tax practice. ${ }^{9}$ The characterisation of tax practice in terms of these

Brian Bix, 'Can Theories of Meaning and Reference Solve the Problem of Legal Determinacy?'(2003) 16(3) Ratio Juris 281 (arguing that Legal Realism is a subset of semantic formalism. Notably this position was recently repudiated in the context of tax jurisprudence in the Wittgenstein article cited here) ('[R]ealists assert that the terms we use refer to objects that exist in our world, and that existence is independent of our beliefs; that the truth of our statements is determined by their correspondence (or lack thereof) with the way the world is.').

${ }^{5}$ See generally Imperial Oil Ltd v Canada; Inco Ltd v Canada, [2006] 2 SCR 447, 2006 SCC 46; see also 26 U.S.C. § 1272 ('Original Issue Discount'); Capital One Financial v Commissioner, (2009) 133 TC No 8.

${ }^{6}$ See Robert Wood, 'The Taxation of Debt, Equity, and Hybrid Arrangements' (1999) 47(1) Canadian Tax Journal 49 ('Over recent decades, [the debt/equity distinction] has increasingly been undermined by derivatives, hybrids, financial engineering, asset replication, and globalization. As the weight has mounted, cracks have appeared in the superstructure. Some believe that a critical pass has been reached and that it is now impossible to establish widespread consistency in the tax treatment of financial arrangements. This state of affairs poses structurally complex challenges for taxation policy.'); see also Dutch Supreme Court, Decisions no 12/03540 and 12/04640 (February 7, 2014); Hewlett-Packard v Commissioner, TC Memo 2012-135, NA General Partnership et al. v Commissioner, TC Memo 2012-17; PepsiCo Puerto Rico, Inc et al v Commissioner, TC Memo 2012-269.

${ }^{7}$ See Antony Ting, 'iTax-Apple's International Tax Structure and the Double Non-Taxation Issue' [2014] British Tax Review 40 ('Transfer pricing rules on intangibles. A key component of the iTax structure is the transfer of the economic rights of Apple's intellectual property to ASI under the cost sharing agreement. Pursuant to the intra-group contract, ASI owns the production and marketing rights of Apple's products for Europe and Asia. ASI does not have to pay any royalties to Apple Inc due to the split economic ownership of the intangible assets.'); see also European Commission Ireland alleged aid to Apple (Decision 3606, 2014); European Commission Luxembourg alleged aid to Amazon (Decision to Initiate Formal Investigation 7156, 2014); European Commission Netherlands alleged aid to Starbucks (Decision 3626, 2014).

${ }^{8}$ See Philip Postlewaite, 'Treasury Creates a Monster. Australia, Beware the Hybrid Entity!' (1996) 16(1) Revenue Law Journal 141 ('Particularly in the international arena, the 'check-the-box' election has revolutionised the practice of international tax law, not always for the good from the standpoint of sound international tax policy. The possibility of being simultaneously a separate entity for tax purposes under the law of a foreign jurisdiction, while being transparent for United States purposes and vice versa, has created planning opportunities previously beyond reach and frequently in conflict with the purpose of the existing international tax legislation.'); see also Treas Reg § 301.7701-3 ('check-the-box' regulations).

${ }^{9}$ Hans Kelsen, The Pure Theory of Law (Knight tr, 2nd edn, University of California Press 1967); Hans Kelsen, 'The Pure Theory of Law and Analytical Jurisprudence' (1941) 55 Harvard Law Review 44; Ronald Dworkin, Taking Rights Seriously (Harvard University Press 1977); Ronald Dworkin, 'Hard Cases' (1975) 88 Harvard Law Review 1057; Karl Llewellyn, The Bramble Bush: Some Lectures on Law and Its Study (Columbia University 1930). 
distinct legal theories is useful because it exposes how globalisation has contributed to the intersection of various approaches to the law in the field of international taxation. For example, in a 'hard' case the Kelsenian tax advisor may find the decisions of US courts in tax cases based on normative principles potentially in violation of the Rule of Law. ${ }^{10}$ Meanwhile, the US tax advisor may find a formalised legal methodology to be divorced from hermeneutic tax language rendering the analysis unrelated to the actual practice of tax law. The current state of the global practice of tax law is thus characterised as a composite of these methods where formalism is assumed in 'easy cases' whereas Dworkinian principle-based reasoning often holds sway in 'hard cases'. ${ }^{11}$ However, contrary to the claims of formalists and Dworkinians about the determinacy of law, tax law is often indeterminate. This is particularly true where tax laws are not enforced consistently. Accordingly, this article suggests that the current practice of tax law should be reconceptualised as simultaneously reflective of formalism and what shall be described here as 'soft' legal realism. ${ }^{12}$

'Soft realism' (explained in detail below) should replace the extant formalistDworkinian composite approach in indeterminate tax cases. ${ }^{13}$ It is similar to Frederick Schauer's 'Tamed Realism', except that it applies only in cases of factual indeterminacy. ${ }^{14}$ This limited realism is thus logically consistent with lawyers assuming an antithetical formalism in cases with determinate facts. ${ }^{15}$ However, because of the unique aspect of tax practice where multinational firms are able to 'manufacture' factual indeterminacy using affiliated legal entities, then perhaps even the majority of tax cases would be legally

\footnotetext{
${ }^{10}$ See generally John Prebble, 'Ectopia, Tax Law and International Taxation' [1997] British Tax Review 383.

${ }^{11}$ For an explanation of 'easy' and 'hard' cases see below Section B.

12 See generally Michael Steven Green, 'Legal Realism as a Theory of Law' (2005) 46 William \& Mary Law Review 1915 ('For any particular lay person, the law, with respect to any particular set of facts, is a decision of a court with respect to those facts so far as that decision affects that particular person. Until a court has passed on those facts no law on that subject is yet in existence. Prior to such decision, the only law available is the opinion of lawyers as to the law relation to that person and to those facts. Such opinion is not actually law but only a guess as to what a court will decide.') citing Jerome Frank, Law and the Modern Mind (Transaction 1930).

${ }^{13}$ For a comprehensive discussion see below Section D.

${ }^{14}$ Frederick Schauer, 'Legal Realism Untamed' (2013) 91 Texas Law Review 749 ('Law is not only about hard cases. There are easy ones as well, and understanding law requires awareness not only of litigated and then appealed disputes, but also the routine application of legal rules and doctrines.') citing Andrei Marmor, Interpretation and Legal Theory (Clarendon Press, 1992).

${ }^{15}$ For a definition of 'formalism' in comparison to 'realism', see Brian Leiter, 'Legal Formalism and Legal Realism: What is the Issue?' (2010) 16(2) Legal Theory 111 ("Formalist" theories claim that ... the law is "rationally" determinate, ie, the class of legitimate legal reasons available for a judge to offer in support of is decision justifies one and only one outcome... the majority of "Realists" advanced a descriptive theory of adjudication according to which (1) legal reasoning is indeterminate (ie, fails to justify a unique outcome) in those cases that reach the stage of appellate review; (2) appellate judges, in deciding cases, are responsive to the “situation-types"_-recurring factual patterns ... that elicit predictable normative responses.').
} 
indeterminate from a formalistic perspective (ie, not cognizable in formalistic terms) ${ }^{16}$ thus leading to double non-taxation, for example. ${ }^{17}$

The article proceeds in the following fashion. First, a primer on legal methodology for tax lawyers is provided as an introduction; second, legal realism in tax methodology is summarised in detail with regard to manufactured factual indeterminacy; third, the role of heuristics (ie, technical tax language) is discussed as a matter of tax methodology; fourth, the relation of General Anti-Avoidance Rules (GAARs) in an era of globalised factual indeterminacy is defined; and finally, the globalisation and dissemination of manufactured factual indeterminacy (primarily by accounting firms) is oriented as a matter of tax jurisprudence.

\section{B. A PRIMER ON LEGAL METHODOLOGY FOR TAX LAWYERS}

The practice of global business taxation can be understood as a medley of formalism, Dworkinian principles-based interpretation and 'Bramble Bush' realism. ${ }^{18}$ Often, in 'easy' cases, the tax lawyer reads the Internal Revenue Code and interprets the provision in a formalistic manner. In hard cases the common law tax lawyer looks to broader principles to determine the best result in true Dworkinian fashion. ${ }^{19}$ However, as a matter of tax planning the tax lawyer must predict what the taxing authority is likely to do as a matter of tax

\footnotetext{
${ }^{16}$ Brian Leiter, 'Rethinking Legal Realism: Toward a Naturalized Jurisprudence' (1997) 76 Texas Law Review $267,277-8$ 'Formalism is committed to the descriptive claim that judges respond primarily - indeed, perhaps exclusively -to the rational demands of the applicable rules of law and modes of legal reasoning'.

17 'Double-non taxation' refers to the lack of income taxation for a multinational firm levied in either the source state or residence state under an applicable tax treaty. The term is essentially a euphemism for the idea that the multinational firm has successfully avoided income taxation on an item of corporate income. The corollary term is 'double-taxation' which is a situation where an item of income is taxed in both the source state and residence under a tax treaty, or where a tax treaty is not in force. In general, tax treaties are entered into to avoid the circumstance of 'double-taxation' and will be entitled: 'Tax Treaty for the Avoidance of Double Taxation', but increasingly to the contrary, multinational firms apply such tax treaties to achieve 'double-non taxation' as opposed to a single layer of taxation; see also Ed Morgan, 'International Tax Law as a Ponzi Scheme' (2011) 34 Suffolk Transnational Law Review 69, 78 'Common law and civil law concepts of trust and agency, to take a prominent example, are at odds domestically and so make for an incompatible tax regime when governments bring together systems in which the agent in one state is the principal in another. Nevertheless, harmonized policies and drafting, extensive use of the OECD model tax convention and commentaries, and mutually reinforcing interpretations, have made domestic applications of tax treaties the most promising source of a substantive international tax regime'.

${ }^{18}$ Karl Llewellyn, 'A Realist Jurisprudence - the Next Step' (1930) 30 Columbia Law Review 431; Karl Llewellyn, 'Some Realism about Realism: Responding to Dean Pound' (1931) 44 Harvard Law Review 1222.

${ }^{19}$ See Green, 'Legal Realism as a Theory of Law' (n 12) 1951 'If legal obligation exists only to the extent that moral reasons for conformity to legal practices can be found, a judge adjudicating a case must interpret legal practices in a moral light in order to assess her legal obligations as a judge ... Because adjudication is fundamentally a moral decision, Dworkin offers as the ideal adjudicator Hercules - that is, a judge who decides cases only after having provided a theory of why participants in legal practices have moral obligations to conform to their demands'.
} 
enforcement. ${ }^{20}$ Tax laws are not always enforced nor always enforced consistently against different categories of taxpayers. As a jurisprudential matter, this is one example of legal realism where the law itself does not determine the legal outcome. ${ }^{21}$ An obvious example is the Accumulated Earnings Tax in the United States, which is applied exclusively against smalland medium-sized businesses rendering large multinational corporations effectively exempt from the tax law. ${ }^{22}$

Such realism is clearly at odds with the Kelsenian formalism assumed in easy cases, where law is treated as though it were determinate and internally complete. ${ }^{23}$ In such cases, the Internal Revenue Code is conceptualised as a set of determinate criteria subject to formalised 'internal' deduction. For example, under this approach one would determine the meaning of the term 'taxable income' by reading the Internal Revenue Code and drawing out the logical inferences from the statute itself. This trust in the determinacy of positive law dominates in Continental Europe and much of Latin America. ${ }^{24}$ For example, tax treaty interpretation is typically performed in a formalistic manner even though the relevant treaties are often only a few pages in length. ${ }^{25}$ This interpretative approach is typically justified in 'negative' Kelsenian terms that such formalism prevents the insertion of normative ideas into the interpretation of tax law. ${ }^{26}$ However, the consequence of viewing tax statutes or treaties as logically sufficient and complete is that other more difficult questions (ie, hard cases) may be left unanswered by such an internalised interpretative approach even where the underlying principles of international tax law might otherwise suggest a clear result. ${ }^{27}$ Thus, legal analysis often appears

\footnotetext{
${ }^{20}$ See generally Max Radin, 'The Theory of Judicial Decision: Or How Judges Think' (1925) 11 ABA Journal 357.

${ }^{21}$ Karl Llewellyn, 'The Normative, The Legal, and the Law-Jobs: The Problem of Juristic Method' (1940) 49 Yale Law Journal 1355 'There is no practicable way, in ordinary life, to get at the notion of rightness without having, somewhere in your mind, a general picture or pattern which the case in hand fits into and fits under'.

${ }^{22}$ Bret N Bogenschneider, 'A Proposal for Equal Enforcement of the AET' (2015) 147 Tax Notes 931 '[T]he enforcement of the AET by the IRS exclusively against small- to medium-sized businesses creates a qualitative difference in the tax law between smaller businesses as compared to large corporations which are effectively exempt'.

${ }^{23}$ See generally Edwin Patterson, 'Hans Kelsen and His Pure Theory of Law' (1952) 40 California Law Review 5; Francois Rigaux, 'Hans Kelsen on International Law' (1998) 9(2) European Journal of International Law 325.

${ }^{24}$ Richard Pildes, 'Forms of Formalism' (1999) 66 University of Chicago Law Review 607 '[F]ormal in that right answers could be derived from the autonomous, logical working out of the system... Although law as this kind of legal science is rarely seen in current American legal education, anyone who has talked with those trained in certain European and other foreign systems will recognize that the view of law as an internally valid, autonomous, and self-justifying science still has much validity'.

${ }^{25}$ Frederick Schauer, 'Formalism' (1988) 97 Yale Law Journal 509, 510 'Formalism is the way in which rules achieve their "ruleness" precisely by doing what is supposed to be the failing of formalism: screening off from a decisionmaker factors that a sensitive decisionmaker would otherwise take into account.'; Ernest J Weinrib, 'Legal Formalism: On the Immanent Rationality of Law' (1988) 97 Yale Law Journal 949.

${ }^{26}$ See Alexander Somek, 'Kelsen Lives' (2007) 18 European Journal of International Law 409.

${ }^{27}$ See below Section C.
} 
similar to an internal logical 'interpretation deduction' without reference to external (ie, morally normative) principles. $^{28}$

Dworkin, on the other hand, in his early work argued that the law is comprised of moral principles and is therefore determinative in all cases. For those who accept this view, legal reasoning requires lawyers to explain and justify the content of legislative instruments and past judicial decisions in terms of such principles. ${ }^{29}$ When applied to tax law, this casts the Internal Revenue Code as capturing a set of determinate moral standards that must be employed by the judge to reach the morally best outcome within their confines. ${ }^{30}$ Such an approach is applied in whole or in part within the US in various practice areas. ${ }^{31}$ From the Kelsenian formalist's perspective, Dworkin's approach is subjective by virtue of its emphasis upon morality. ${ }^{32}$ However, Dworkin would deny this because lawyers arguing before a court and judges deciding upon the appropriate outcome do not make judgements based upon subjective preferences but upon reasons that they take to actually justify their conclusions.

\section{Kelsen and Tax Law}

In the Pure Theory of Law and Analytical Jurisprudence, Kelsen sets out to separate the idea of law from other systems of social order, which for him included morality. ${ }^{33}$ In his words: 'The pure theory of law is a theory of positive law; a general theory of law, not a presentation or interpretation of a special legal order ... [T] he pure theory of law simply declares itself incompetent to declare ... what constitutes justice. ${ }^{34}$ In Kelsen's somewhat idiosyncratic usage, 'Justice means the maintenance of a positive order by applying it conscientiously.' 35

\footnotetext{
${ }^{28}$ Jonathan Yovel, 'Relational Formalism and the Construction of Financial Instruments' (2011) 48 American Business Law Journal 371, 376 'We could imagine a... Continental-style code that provides specific rules for various commercial occurrences. Another possible architecture framework is formalism.'; see also Thomas G Kelch, 'An Apology for Plain-Meaning Interpretation of the Bankruptcy Code' (1994) 10 Bankruptcy Development Law Journal 289 (applying linguistic precepts to bankruptcy law.); but see Michael Steven Green, 'Hans Kelsen and the Logic of Legal Systems' (2003) 54 Alabama Law Review 365, 368 'Kelsen sought to save the logical analysis of legal systems by adopting a Kantian epistemology of legal meaning'.

${ }^{29}$ A complete discussion of the early versus late phases of Dworkinian thought is beyond the scope of this work. Because of its moral determinacy, Dworkinian theory is separate from the theory of legal realism given the potential for indeterminacy under the realist approach to legal interpretation.

${ }^{30}$ See generally Jeffrey B Hall, 'Taking "Rechts" Seriously: Ronald Dworkin and the Federal Constitutional Court of Germany’ (2008) 9 German Law Journal 771.

${ }^{31}$ See generally Edward J McCaffery, 'Tax's Empire' (1996) 85 Georgetown Law Journal 71, 75 'In particular, neither formalist nor utilitarian approaches give us tools for reasoning about the appropriate ends-final or intermediate goals, or "principles" in Dworkin's word-in tax'.

32 Michael Steven Green, 'Dworkin's Fallacy, or What the Philosophy of Language Can't Teach us about the Law’ (2003) 89 Virginia Law Review 1897.

${ }^{33}$ See Thomas Christiano and Stefan Sciaraffa, 'Legal Positivism and the Nature of Legal Obligation' (2003) 22 Law and Philosophy 487.

${ }^{34}$ Kelsen 'The Pure Theory of Law and Analytical Jurisprudence' (n 9) 45.

35 ibid 49.
} 
Thus, law may be an idealised abstraction for Kelsen, but it is totally separate from moral thought. ${ }^{36}$ Christoph Kletzer described this aspect of Kelsenian theory as 'negative positivism':

The validity and the content of the positive law cannot be derived from moral premises, then positivism present itself as a negative or relative position, ie, as the rejection of certain normative relations of derivation. Positivism, understood in this way, first and foremost tells us what law is not. ${ }^{37}$

In the General Theory of Norms Kelsen describes norms as follows: 'Only norms, provisions as to how individuals should behave, are objects of jurisprudence, never the actual behavior of individuals'. ${ }^{38} \mathrm{He}$ also sets forth the idea of an authorising norm as the initial statement of the 'ought' (soll). ${ }^{39}$ Kelsen says: 'Every system of values, especially a system of morals and its central idea of justice, is a social phenomenon, and hence differs according to the nature of the society within which it arises. ${ }^{40}$ All systems of norms, law included, are structured in the same way for Kelsen: they are hierarchical systems with an ultimate authorising norm at the top. This is to transition the theory from 'negative' positivism to a version of 'positive' positivism. Kletzer explains:

In any legal system whether a given norm is legally valid depends entirely on the law; [then] The validity and the content of the positive law is based on the law itself, or, which is the same: on nothing ... Now, if the validity of every legal norm necessarily depends on the validity of another legal norm, then we can demonstrate, in line with the classical pyrrhonic argument, that there can exist no valid legal norms at all, since the resulting chain of derivations of validity... leads to infinite regress. ${ }^{41}$

For Kelsen, this ultimate authorising norm or Grundnorm is the logical basis for all positive norms within its system. The Grundnorm itself is content-free, merely endorsing the highest positive norm of the system. This can be contrasted with some versions of natural law, ${ }^{42}$

\footnotetext{
${ }^{36}$ This separation of law and morality is commonly referred to as the 'separation thesis' in Anglo-American jurisprudence. See John Gardner, 'Legal Positivism: 5 1/2 Myths' (2001) 46(1) American Journal of Jurisprudence 199; Dennis Patterson, 'Explicating the Internal Point of View' (1999) 52 SMU Law Review 67, 69 'Central to legal positivism is the denial of any necessary conceptual connection between law and morality (the separation thesis). In simple terms, the idea is that there is a logical distinction between statements of what the law is or requires and statements about whether the law is good or just'.

${ }^{37}$ Christoph Kletzer, 'Absolute Positivism' (2013) 42(2) Netherlands Journal of Legal Philosophy 89.

${ }^{38}$ Kelsen 'The Pure Theory of Law and Analytical Jurisprudence' (n 9) 50.

${ }^{39}$ See Kelsen 'The Pure Theory of Law and Analytical Jurisprudence' (n 9).

40 ibid.

${ }^{41}$ Kletzer (n. 37) at 91. Kletzer also makes reference to the 'logical circle' and 'dogmatic acceptance' however the first 'infinite regress' argument is sufficient for the theory presented here.

${ }^{42}$ See generally John Finnis, Natural Law and Natural Rights (Clarendon Press, 1980) (providing a framework for moral values based on a description of basic human goods).
} 
which see normative systems, law included, as ultimately grounded in fundamental moral truths. ${ }^{43}$

To understand how a Kelsenian would conceptualise tax law, consider the American case of Commissioner v Glenshaw Glass, where it was held that the terms of the Sixteenth Amendment authorise the taxation of all forms of income. ${ }^{44}$ This high level legal norm is further concretised by those contained in the Internal Revenue Code provisions that govern income taxation. These Internal Revenue Code norms were established by Congress pursuant to its authority to legislate, which is also established by the Constitution. Based on such observations, the Kelsenian would claim that the duty to pay income tax under US law can be traced back to the Constitution through a hierarchy of legal norms. At the top of this hierarchy is the Grundnorm that validates the legal force of the Constitution. At the bottom, legal duties to pay tax take the form of norms authorising sanctions in the event that the required tax is not paid. ${ }^{45}$ From a Kelsenian perspective, compliance with the duty to pay tax is 'right' relative to the normative demands of the law. ${ }^{46}$

All systems of legal norms exist alongside other systems of social norms. Controversially, Kelsen viewed morality and ethics, as well as custom and convention, as systems of this other sort. As such, '[t]he methodological purity of the science of law is jeopardised' where ethics or morality find their way into law. ${ }^{47}$ The implication of this is that normative values are to be excluded, both from the analysis of law and from legal reasoning, to maintain theoretical clarity and to preserve the content of legal norms themselves. As previously mentioned, this view of law is grounded in a relativistic theory of values. ${ }^{48}$ Rather

\footnotetext{
${ }^{43}$ See Jörg Kammerhofer, 'International Legal Positivism in a Post-Modern World: A Proposal for Greater Focus in Scholarship' (2013) AjV Newletter 03/13 'We had, at first independently of each other, both come to the conclusion that the attacks on positivism we had read did not do justice to the newest developments in that family of approaches as applied to international law'.

${ }^{44}$ Commissioner v Glenshaw Glass Co, (1955) 348 US 426.

${ }^{45}$ Kelsen 'The Pure Theory of Law and Analytical Jurisprudence' (n 9) 49 'V. The Legal Duty. The pure theory of law stresses the primary character of the concept of duty in relation to that of right, just as Austin does. "Duty is the basis of Right." To say that an individual is legally obligated to observe certain conduct means that a legal norm provides a sanction for contrary behavior, a delict. Normally the sanction is directed against the individual who has committed the delict'.

${ }^{46}$ Green, 'Dworkin's Fallacy, or What the Philosophy of Language Can't Teach us about the Law' (n 32 ) 381 '[I]f A authorizes B to create law, then commands that are within the scope of that authorization are necessarily legally valid norms. Finally, like the logically true sentence, the legal meaning of the creation of the first constitution as an act of authorization is necessary, in a manner that does not depend upon the legal meaning of any other event'.

${ }^{47}$ Kelsen, Pure Theory of Law (n 9) 59, 66 'If only relative moral values are presupposed, then the postulate that the law ought to be moral, that is, just, can only mean that the formulation of positive law ought to conform to one specific moral system among the many possible systems'.

${ }^{48}$ John Prebble, Rebecca Prebble and Catherine Vidler Smith, 'Legislation with Retrospective Effect, with Particular Reference to Tax Loopholes and Avoidance' (2006) 22 New Zealand University Law Review 17; but see Matthew H Kramer, 'When is there not one Right Answer?' (2008) 53 American Journal of Jurisprudence 49
} 
than resulting in no justice under such relativity, '[i]t means rather that values are relative, not absolute, that justice is relative not absolute' ${ }^{49}$ By keeping law pure, the Kelsenian hopes to leave untouched the notion of justice relative to posited legal norms. From this perspective, any reference to the practice of 'treaty-shopping' ${ }^{50}$ or 'double non-taxation' by multinational firms, for example, is not appropriate because by seeking the preferred economic outcome, non-legal normativity has been inserted into the legal analysis. ${ }^{51}$

\section{Dworkin and Tax Law in Hard Cases}

Dworkin wrote on the nature and interpretation of law in general but with reference to hard cases in particular. ${ }^{52}$ Hard cases can arise for a number of reasons but in the tax context they typically emerge when the meaning of a provision of a tax statute is disputed. Schauer describes them as follows:

To the extent that one can find an answer to a question by a straightforward reading of rules, other factors may make a case hard. A case that seems linguistically easy may be hard if the result announced by the language is inconsistent with the 'purpose' of the rule. In such cases the tension between the plain meaning of the words and the reason for using those words creates a hard case, in much the same way that linguistic imprecision creates a hard case. ${ }^{53}$

As an example, the tax issue might be how to levy tax on a discounted bond prior to the implementation of the Original Issue Discount (OID) rules in the mid-1980s. As a general rule, hard cases are more likely to arise where the legislature is unable to agree on all of the specific terms of a tax statute in advance and so drafts the code in a principled format and leaves it to the taxing authority to work out the details. The Uniform Commercial Code (UCC) takes this

\footnotetext{
'If legal cognition encounters legal norms that contradict one another in content, it seeks, by interpreting their meaning, to resolve the contradiction as a mere pseudo-contradiction. If this effort fails, legal cognition disposes of the material to be interpreted, disposes of it as lacking in meaning altogether and therefore as non-existent in the legal sphere qua realm of meaning'.

49 ibid 67.

50 'Treaty-shopping' refers to the formation of an affiliate entity by a multinational in a jurisdiction with a favorable tax treaty network solely to obtain the tax benefit from the treaty network. See generally Leslie Green, 'The Concept of Law Revisited' (1996) 94 Michigan Law Review 1687 'The reason for the validity of a norm can only be another norm, and thus the ultimate reason for the validity of law must be a norm rather than a matter of fact. This "transcendental-logical presupposition" Kelsen called the Grundnorm. So while Kelsen is a positivist - law may have any content and there is no necessary connection between law and morality - he is not a social constructivist ... sociology, psychology, political theory, economics, etc - are for him all "alien elements" that lead only to the "adulteration" of a pure theory of law".

51 James Maxeiner, 'Thinking Like a Lawyer Abroad: Putting Justice into Legal Reasoning' (2012) 11 Washington University Global Studies Law Journal 55; citing Frederick Schauer, Thinking Like a Lawyer: A New Introduction to Legal Reasoning (Harvard University Press, 2012).

52 See Dworkin 'Hard Cases' (n 9).

${ }^{53}$ Frederick Schauer, 'Easy Cases' (1985) 58 Southern California Law Review 399, 415.
} 
approach as a matter of contract law. ${ }^{54}$ Thus, the law is intentionally vague. ${ }^{55}$ Problems also arise where two laws require different outcomes, as now occurs with tax treaty interpretation in the US, where the treaty is in conflict with a provision of domestic tax law. ${ }^{56}$ Further problems potentially arise in determining when, if at all, provisions of tax statutes have clear linguistic meanings that make them appropriate for formalistic review. ${ }^{57}$ But a conflict of principles requires weighting and balancing, as Donato explains:

By weight Dworkin means the measure of a principle's significance and authority. When principles conflict, the principle with the greater weight serves as the principle that influences the decision. The outweighed principle does not become invalid; it is, for that one case, simply overcome. ${ }^{58}$

This approach is downstream of Dworkin's most famous philosophical claim, which is that legal reasoning demands that the law be presented as having 'integrity'. The integrity of the law is respected when 'the legal interpreter respects law's wholeness, continuity, and consistency. ${ }^{59}$ The idealised judge Hercules is used by Dworkin to illustrate how this exercise must be undertaken:

Accomplishing the Herculean task of establishing [principles that] fit [the relevant past political decisions] does not end the judge's work. He still must choose one of the remaining principles to resolve the case, and he does so by choosing the one that shows the case law and the community's political-legal history in their best light. He must make his substantive choice on grounds, not of aesthetics, but of political morality. The judge must select the principle that reveals the legal order 'to be the best it can be from the standpoint of substantive political morality. ${ }^{60}$

\footnotetext{
54 Yovel, 'Relational Formalism and the Construction of Financial Instruments' (n 28) 395-6 '[J]ust as constructing UCC provisions using a relational approach to formalism promotes relevant normative goals better than does strict formalism. As a matter of interpretative strategy, this approach is more coherent with the general approach of the UCC, in which formal rules are seen as a contextualized mode of regulation, used for policy purposes and not as an inflexible legal regime of pure doctrine'.

${ }^{55}$ Schauer, 'Formalism' (n 25) 536 'Commonly, we plan for these frustrations by rendering the norms of the law less determinate and thereby using vagueness as the tool by which we plan for the open texture of experience'.

${ }^{56}$ Jamieson v Comm'r of Internal Revenue, (2008) 95 TCM (CCH) 1430.

${ }^{57}$ Frank Diedrich, 'Maintaining Uniformity in International Uniform Law via Autonomous Interpretation: Software Contracts and the CISG' (1996) 8 Pace International Law Review 303, 314 'Nevertheless, a separate problem with interpreting International Uniform law consists of the initial categorization of a term as "unclear." In such a situation, every lawyer unavoidably applies and interprets international uniform law by using his or her "home law." This approach is problematic in that there may be objectively justified doubts of a "reasonable above national bystander's" proper interpretation of a term in the Convention, whereas the meaning is well-defined under a given "home law",

58 James Donato, 'Dworkin and Subjectivity in Legal Interpretation' (1988) 40 Stanford Law Review 1517, 1531. 59 ibid 1533.

${ }^{60}$ ibid 1523-4 ('The ability of Kelsen's theory to achieve this height of purity depends on the efficacy of his concept of the basic norm. For both legal science and the practical world of legal norms, the basic norm validates
} 
As such, Dworkin shares with the formalists a belief that the law is determinate but he differs as to why. For him, determinate answers are possible through the application of moral principles because political morality holds determinate truths.

\section{The Bramble Bush in Tax Jurisprudence}

The Bramble Bush refers to a version of legal realism popularised by Karl Llewellyn, where he avers that the adjudication (and enforcement) of the law is the law. ${ }^{61}$ As explained by Richman:

Llewellyn's argument was that law is not about the externally imposed rules for conduct, but rather disputes and how one predicts what someone is going to do in order to resolve the dispute. Law is not about what is 'right,' but rather, and almost exclusively, lawyers devote themselves to predicting what a particular court will do. Law is 'what law does.' More important than 'right' and 'wrong' is that disputes are settled; this is the function and province of law. ${ }^{62}$

A great deal of general jurisprudence focuses on adjudication rather than enforcement practices, ${ }^{63}$ but in the tax context enforcement practices by taxing authorities are a crucial aspect of practice that any realist approach must account for. For example, income tax laws generally require taxpayers to self-report so, depending on the sophistication of their legal advice, they may be able to engage in tax avoidance before filing of the return itself. Only after the voluntary reporting of taxable income does the taxing authority begin enforcement. Insofar as the enforcement of tax laws depends on a voluntary reporting system Llewellyn's observation is particularly applicable. This is because there may be factual or legal indeterminacy on a particular transaction but also enforcement indeterminacy in that an aggressive tax transaction may never be challenged. ${ }^{64}$

\footnotetext{
other norms through a test of creation. Since norms are neither true nor false, a norm's validity must flow as a grant from some higher norm. At the apex of this normative chain lies the basic norm. This norm constitutes the highest validity-granting authority in the legal order; it is "the presupposed starting point of a procedure: the procedure of positive law creation." As a procedure, the basic norm confers validity by testing a lower norm's genesis rather than its content. A lower norm created in accordance with the procedures laid down by the basic norm is a valid norm.') (citations omitted).

${ }^{61}$ See Llewellyn (n 9).

${ }^{62}$ Steven Richman, 'Legal Philosophy: A Palimpset' (2000) 205(Oct) NJ Law 10.

${ }^{63}$ See Leiter (n 15).

${ }^{64}$ See Zoe Prebble and John Prebble, 'The Morality of Tax Avoidance' (2010) 43 Creighton Law Review 693 'If an avoidance scheme cannot achieve a reduction in tax liability without secrecy, it is hard to see it as legal in any robust sense. A scheme that will clearly be struck down if it should ever be challenged seems to be only weakly or contingently within the law'.
} 


\section{Formalism and Easy Cases}

In run-of-the-mill tax disputes (ie, easy cases) the assumption of formalism often allows lawyers to quickly and easily resolve matters. Frederick Schauer described the 'easy case' with regard to Constitutional law jurisprudence as follows:

Once we expand our notion of a 'case' to include all legal events, it becomes clear that there are easy cases in constitutional law - lots of them. The parties concerned know, without litigating and without consulting lawyers, that Ronald Reagan cannot run for a third term ... that a twenty-nine year-old is not going to be President of the United States. I have equivalent confidence that I will not receive a notice in the mail informing me that I must house members of the armed forces in my spare bedroom; that criminal defendants in federal courts cannot be denied the right to be represented by a qualified lawyer for whom they are willing to pay; and that the next in line to succeed to the Presidency in the event of the President's death is the Vice-President, and not the Secretary of the Interior, the Congressman from Wyoming, or the quarterback for the Philadelphia Eagles. ${ }^{65}$

Similarly, in tax practice there are also lots of 'easy cases'. The parties know, without consulting lawyers: that US persons are taxable on worldwide income; that capital gains are considered as 'taxable income'; that if a taxpayer excludes interest income from the bank that she will receive a notice from the taxing authority; that tax protestors may not claim the Sixteenth Amendment of the US Constitution as invalid; and that corporate taxpayers are able to defer taxation of foreign income, thereby greatly reducing their worldwide effective tax rate in comparison to individual and small business taxpayers. ${ }^{66}$ Notably, many questions of law related to individual taxation are highly susceptible to the assumption of formalism because of their clearly determinate nature, whereas, as we shall see, problems emerge in multinational tax planning because of its scope for greater indeterminacy. The application of a formalistic interpretive method in the context of more difficult cases (such as the tax planning activities of multinationals), under the assumption of legal determinacy, however, is not a viable or realistic approach to tax law because legal and factual determinacy cannot be assumed in the context of taxation.

\footnotetext{
${ }^{65}$ Schauer, 'Easy Cases' (n 53) 414.

${ }^{66}$ See Bret N Bogenschneider, 'A Theory of Small Business Tax Neutrality' (forthcoming, 2015) 15 Florida State University Business Review; Bret N Bogenschneider, 'The Effective Tax Rates of US Firms With Permanent Deferral' (2014) 145 Tax Notes 1391; Bret N Bogenschneider, 'The Effective Tax Rate of US Persons by Income Level' (2014) 145 Tax Notes 117.
} 


\section{C. 'MANUFACTURED' FACTUAL INDETERMINACY AS A MATTER OF TAX}

\section{LAW}

The existence of factual indeterminacy (and also the potential for its 'manufacture') is well known to tax lawyers. The Organisation for Economic Co-operation and Development (OECD) initiative on Base Erosion and Profit Shifting is directed in part at tax planning intended to create factual indeterminacy. Factual indeterminacy can be successfully manufactured by multinationals with a transaction intentionally designed to fall through the cracks of a tax treaty, for example. The OECD has now called for a Limitation on Benefits ('LOB') provision in the OECD model treaty in an attempt to limit this sort of tax planning. However, the Holmesian 'bad man' of international tax planning is quite clever, and thus advisors warn that even an LOB provision would not prevent manufactured factual indeterminacy from resulting in double non-taxation under applicable tax treaties. ${ }^{67}$

Insofar as manufactured factual indeterminacy actually creates hard cases in the tax context, formalist methodology fails to resolve the matters at issue. This occurs on the case of an indeterminate fact pattern. In this case, the indeterminate fact pattern is intentionally designed to fall outside the framework for formalistic legal interpretation of the tax law. A common example is the result of 'double non-taxation' under formalist tax treaty interpretation. $^{68}$

As mentioned above, the tax authorities believe the object and purpose of tax treaties is to avoid double taxation and double non-taxation in general. This is in accordance with the Commentaries on Article 23 of the OECD Model Convention, which state that the basic function of Article 23 would be to eliminate double taxation. This view cannot be shared fully. The tax treaties restrict the taxing rights of the contracting states in the areas they are regulating. A further purpose cannot be deduced ... If the contracting states want to exclude non-taxation, they have to insert subject-to-tax clauses. If they

\footnotetext{
${ }^{67}$ See Romero Tavares, 'The "Active Trade or Business" Exception of the Limitation on Benefits Clause' in Michael Lang and others (eds) Base Erosion and Profit Shifting: The Proposals to Revise the OECD Model Convention (IBFD 2015); see also United States Model Tax Treaty (2006), Article 23 <www.treasury.gov/presscenter/press-releases/Documents/hp16801.pdf> accessed 3 September 2015.

${ }^{68}$ See eg Christian Kahlenberg, 'Prevention of Double Non-taxation: An Analysis of Cross-Border Financing from a German Perspective' (2015) 43(3) Intertax 218; see also Craig Elliffe and Andrew Yin, 'Hybrid Entity Double Taxation: A Case Study on the Taxation of Trans-Tasman Limited Partnerships' (2011) 21(1) Revenue Law Journal <http://epublications.bond.edu.au/cgi/viewcontent.cgi?article $=1215 \&$ context $=r l j>$ accessed 8 August 2015.
} 
do not stipulate this clause, there is no legal basis to assume that the states wanted to prevent double non-taxation. ${ }^{69}$

Accordingly, if the fact pattern at issue falls outside the positivist framework of the tax treaty then the legal analysis is rendered null. In other words, the interpretational result of 'double non-taxation' (or 'double taxation') says that the tax treaty interpretation cannot resolve the interpretational dispute. ${ }^{70}$

\section{D. 'SOFT REALISM', WITTGENSTEIN AND TAX JURISPRUDENCE}

An application of formalism with regard to easy cases, and then legal realism in the more difficult cases, might be referred to as a version of 'soft realism'. The idea of soft realism is that in certain cases tax law is determinative enough to allow for a formalistic analysis, whilst in others indeterminacy necessarily pertains. Accordingly, a hierarchy of methods would be better suited as an interpretational method as a matter of international tax law. This hierarchy is:

(i) Easy Cases: Formalist legal interpretation of a statute or tax treaty provision leads to determinative result. As applied to the easy cases of tax law a formalistic approach (which is applied in most jurisdictions) tends toward consistency and predictability in the application of law to simple fact.

(ii) Cases of Legal Indeterminacy: Formalist legal interpretation of a statute or tax treaty provision fails to reach a determinative result (eg, double non-taxation). This potential for legal indeterminacy was questioned by Dworkin, for example, and not all jurisdictions allowed for a null legal result (ie, double non-taxation). ${ }^{71}$

\footnotetext{
${ }^{69}$ Judith Herdin and Michael Schilcher, 'Avoidance of Double Non-Taxation in Austria' in (Michael Lang ed) Avoidance of Double Non-Taxation (Linde Verlag 2003).

${ }^{70}$ ibid ('The mere fact that there is a treaty that avoids double taxation in some aspects does not suggest that the states also wanted to avoid double non-taxation.'); See also Marjaana Helminen, 'The Problem of Double NonTaxation in the European Union - To What Extent Could this Be Resolved through a Multilateral EU Tax Treaty Based on the Nordic Convention?'(2013) 53(7) IBFD European Taxation 'The state in which the company is established may not tax the profits of the company because the state regards the company as a transparent entity and the owners of the entity are non-residents with no permanent establishment (PE) in that state. At the same time, the state of residence of the owners of the company may not tax the profits of the company until profits are actually distributed to the owners of the company because the state regards the company as a non-transparent foreign entity'.

${ }^{71}$ Note that Continental Europe and Latin America by applying a formalistic method do not necessarily resolve hard cases of legal indeterminacy resulting in 'double non-taxation' as a matter of law, for example. In other common law jurisdictions, such as the United States, courts may resolve hard cases of tax law by looking to outside 'normative' principles. Hence, as it stands, the current practice of international tax law is not consistent in the case of strictly legal indeterminacy.
} 
Before going on we must once and for all distinguish factual indeterminacy and strictly legal indeterminacy. Legal indeterminacy arises in the situation where formalistic legal analysis cannot provide a determinate result on the application of a known set of facts. Factual indeterminacy pertains in situations where the facts themselves are disputed and cannot clearly be settled and comprise the actual subject of the dispute. In tax law practice, indeterminacy is typically of the factual kind. ${ }^{72}$ Hence, it follows:

(i) Case of Factual Indeterminacy: Formalised legal interpretation of a statute or tax treaty provision fails to reach a determinative result (ie, double non-taxation). Tax heuristics are consulted to resolve the problem and appropriately classify the facts of the case.

(ii) Case of 'Manufactured' Factual Indeterminacy: Formalised legal interpretation of a statute or tax treaty provision fails to reach a determinative result (ie, double nontaxation). Tax heuristics are consulted to resolve the problem and appropriately classify the facts of the case. In the case of 'first impression' tax heuristics will evolve by operation of common law (the first case of this sort might also be properly resolved pursuant to the GAAR).

Notably, a pure formalist method does not account for the possibility of factual indeterminacy in the tax law. Rather, all indeterminacy is simply lumped into the general idea of legal indeterminacy. ${ }^{73}$ This presumption creates the ill-fated potential for tax planning in the form of manufactured factual indeterminacy (to be characterised under the general category of legal indeterminacy) when such was designed exactly to be indeterminate as a matter of fact. Similarly, Dworkinian theory assumes all legal matters are determinate as a matter of law. However, within international tax law factual indeterminacy is the predominant consideration of the tax law. Thus, the Dworkinian approach also does not resolve the problem of manufactured factual indeterminacy.

\section{Wittgenstein and Tax Heuristics}

A hermeneutic methodology for law contemplates an interpretational method as determined by the technical language of legal practitioners. This fits into a general realist theory where

\footnotetext{
${ }^{72}$ The difference in interpretive method as between various taxing jurisdictions (eg, as between Continental Europe and Latin America versus the US) in the case of strictly legal indeterminacy is not the thesis of this article which relates to manufactured factual indeterminacy. This is a different type of indeterminacy. For an example of legal indeterminacy in the case of inconsistent enforcement of laws, see Bogenschneider, 'A Proposal for Equal Enforcement of the AET' (n 22).

${ }^{73}$ See generally Kletzer (n 37) at 97 'One cannot ask a legal question, one cannot say or think anything legal without already having presupposed the basic norm ... The law presupposes its own validity. It is thus the law itself and not we that presupposes the basic norm and presupposing the basic norm the positive law posits itself'.
} 
'context [does not] preempt form, but precisely because it considers both to operate in the same practical, normative, and institutional space.' 74 Hence, as Yovel says: 'Devising and interpreting legal language means constantly accommodating useful forms of action stemming from relational concerns like reliance, even in a legal field dominated - and rightly so - by matters of form. ${ }^{75}$ As such, a strict formalised practice of tax law is less able to adapt to complex circumstances. ${ }^{76}$

John Prebble at one point accused tax law of 'incomprehensibility' because the technical tax language or 'heuristics' comprises its own 'Ectopia' or special language. ${ }^{77}$ However, the existence of tax heuristics actually counts in favour of taxation as a scientific discipline because it tends toward replicable results in application. ${ }^{78}$ In order to understand this point more clearly, we must direct our attention to the 'linguistic turn' in postmodern philosophic thought, which is often associated with Ludwig Wittgenstein. ${ }^{79}$ Kavka described the target of the 'linguistic turn' in the following terms: 'The common misconception about learning language is that it consists mainly in adults teaching children the names of things by ostensive definition - that is, by pointing to things and saying their names. ${ }^{80}$ More recently, this mistake has been described as 'semantic formalism' (ie, label-making) as a form of linguistics, which was a major target of Wittgenstein's philosophical critique. ${ }^{81}$

\footnotetext{
74 Yovel, 'Relational Formalism and the Construction of Financial Instruments' (n 28) 402.

75 ibid 407.

76 See Jonathan Yovel, "What is Contract Law "About"? Speech Act Theory and a Critique of "Skeletal Promises"' (2000) 94 Northwestern University Law Review 937, 954 'Playing such games, then, is not just playing by presupposed rules. It is also the possibility of putting forth alternative practices, alternative "rules" to face whatever lot they may in markets and histories of practice. This is, I argue, not only a valid reading of Wittgenstein, but an approach supported by contemporary jurisprudential canons as well'.

${ }^{77}$ See John Prebble, 'Why is Tax Law Incomprehensible?' [1994] British Tax Review 380; Thomas O Main, 'The Word Commons and Foreign Laws' (2013) 46 Cornell International Law Journal 219, 241-2.

${ }^{78}$ In philosophical terms, this debate is referred to as 'metasemantics'. See Green, 'Legal Realism as a Theory of Law' (n 12) 1484 ("But there is a different sense of the word "semantic" which refers not to claims about what the content of a concept (or the meaning of a word) is, but rather to claims about how this content or meaning is generated. Sometimes the term "metasemantic" is used to identify semantic claims in this second sense ... The metasemantic view that concepts are criterial can be understood as conventionalist because concepts are shared only to the extent that there is current agreement concerning the criteria for the concepts' use.'); For a discussion of 'criteria' in metasemantics see Dworkin, Justice in Robes (Harvard University Press, 2006).

${ }^{79}$ See Louis E Wolcher, 'Ronald Dworkin's Right Answers Thesis Through the Lens of Wittgenstein' (1997) 29 Rutgers Law Journal 43; Dennis Patterson, 'Wittgenstein and Constitutional Theory' (1994) 72 Texas Law Review 1837, 1854-55 'The legacy of philosophy from the middle of this century to the present has been the systematic replacement of foundationalist epistemology with holism, the substitution of referential theories of language with an emphasis on speech as action, and a general movement away from the individual as the foundation of empirical, linguistic, and moral judgment'.

${ }^{80}$ Gregory S Kavka, 'Wittgensteinian Political Theory' (1974) 26 Stanford Law Review 1455, 1458.

${ }^{81}$ Bogenschneider, 'Wittgenstein on Why Tax Law is Comprehensible' (n 4) 259 'In Cartesian philosophy thought relates to various a priori aspects of the human mind, typically given as space and time. And, because I think, I therefore conclude that I am part of the physical world'.
} 
Modern thinkers reasonably disagree on whether the linguistic turn holds any relevance for contemporary jurisprudence. ${ }^{82}$ But, whether or not the linguistic turn ought to be adopted by those studying the nature of law does not necessarily resolve whether it ought to apply to tax law practice. Along these lines, Yovel argues that a flexible approach to meaning is also applied in contract law, which is strongly analogous to tax law in this respect. Yovel sees the law of financial instruments as a form of Wittgensteinian 'language game':

This flexible approach to meaning is very much like what the philosopher Ludwig Wittgenstein termed 'family likeness,' a framework legal scholars have found useful since the 1950s. Some things, Wittgenstein tells us, are like other things not because they share a presupposed set of necessary or sufficient conditions, but because they share nonexclusive, nonconclusive elements that are not privileged as 'necessary.' Furthermore, they may not be defined in advance, prior to practice. Wittgenstein's famous example of 'like things' was the set of all games. ${ }^{83}$

A similar approach to that of the heuristics method was given by Stavropoulos as theory generation by reference to data from legal practice. ${ }^{84}$ Bix summarised as follows:

Under Stavropoulos' approach, to determine meaning and application of a legal term, one constructs theories about the nature of a legal concept, based on the data from legal practice, which includes archetypical applications as well as claims about the nature of the relevant property made in the course of defending these applications - typically judicial decisions. $^{85}$

Similarly, in the context of taxation and 'manufactured' factual indeterminacy the technical legal language of taxation should be expected to evolve terminology sufficient to describe new iterations of fact. Tax heuristics represents a nomenclature devised by tax experts confronted with the problem in tax practice. And, such heuristics of the tax profession can be used to determine the meaning and application of legal terms in hard cases. Indeed, the application of tax heuristics may often imply a result implied by formalistic interpretations of

\footnotetext{
82 Joseph Blocher, 'Nonsense and the Freedom of Speech: What Meaning Means for the First Amendment' (2014) 63 Duke Law Journal 1423, 1447 ('Language can represent every possible fact in the world and there are no otherworldly facts. After all, Wittgenstein himself said that " $[\mathrm{t}]$ he limits of my language mean the limits of my world."') (citations omitted); Green, 'Legal Realism as a Theory of Law' (n 12) 1898 'The philosophy of language generally has no jurisprudential consequences.'; Main (n 74) at 234-5 'Because there is an arbiter of meaning, legal language is fundamentally different from ordinary discourse. When analyzing the interaction of meanings in such legal language, the existence of a meaning or meanings is much more important than either the content of any particular word's meaning or the philosophical methodology by which a word's meaning is derived'.

83 Yovel, 'Relational Formalism and the Construction of Financial Instruments' (n 28) 402.

${ }^{84}$ Nicos Stavropoulos, Objectivity in Law (Clarendon Press, 1996).

${ }^{85}$ Bix (n 4) 286.
} 
an easy case. This is distinguishable from Dworkinian theory because tax heuristics are not, and do not purport to be, moral principles.

\section{The Example of a Shiny, Yellow, Ductile Metal, or 'Gold'}

The proposal that we make use of language in legal practice to render hard cases more determinate has been challenged on the grounds that not all words are subject to interpretation. ${ }^{86}$ For example, Leslie Green points out that the substance the word 'gold' references cannot be subject to interpretation because it is necessarily a 'shiny, yellow, ductile metal. ${ }^{87}$ His claim is that the ordinary meaning of 'gold' is settled, by common usage, as referring to such a substance and that insofar as scientific usage is concerned, 'gold' can be defined with reference to the periodic table of elements. This means that neither gold itself, nor either its common or scientific usage can be interpreted as a legal or linguistic convention in use:

[I]t would be absurd to conclude from the fact that the meaning of 'gold' is fixed by an interpretive practice that gold is an interpretive practice - rather than, say, a heavy, yellow, ductile metal. If the interpretive theory of meaning is correct, one determines what should be called 'gold' by participating in the interpretive practice of using the word 'gold.' And, at this point, such participation involves calling heavy, yellow, ductile metals - not interpretive practices - 'gold.' 88

But, in taxation practice, as opposed to the common or scientific usage of the term, both the meaning and extension of 'gold' is so problematic that it is by no means clear that it tracks either non-legal meaning. The Internal Revenue Code defines gold itself as a 'collectible. ${ }^{89}$ But, this definition admits not only raw quantities of shiny, yellow and ductile metal, but also currency, jewellery, industrial inventory and financial instruments, such as the Gold Exchange Traded Fund (Gold ETF). Thus, 'gold' can mean a share of stock in an exchange traded fund representing an amount of gold that the owner does not possess. Now, the question is how shall

\footnotetext{
${ }^{86}$ Green, 'Dworkin's Fallacy, or What the Philosophy of Language Can't Teach us about the Law' (n 32 ) 382 'The most important challenge to Kelsen is from empiricist approaches to jurisprudence. Rather than understanding legal meaning in terms of abstract objects, the empiricist argues that it can instead explain it in fully empirical terms. Legal meaning can be understood in terms of the practices or conventions within a society'.

${ }^{87}$ Green, 'Legal Realism as a Theory of Law' (n 12) 1916-7.

88 ibid.

${ }^{89}$ Internal Revenue Code $\S 1408(\mathrm{~m})(3)$ 'For purposes of this subsection, the term "collectible" shall not include(A) any coin which is- (i) a gold coin described in paragraph (7), (8), (9), or (10) of section 5112 (a) of title 31, United States Code ... (iv) a coin issued under the laws of any State, or (B) any gold, silver, platinum, or palladium bullion of a fineness equal to or exceeding the minimum fineness that a contract market (as described in section 7 of the Commodity Exchange Act').
} 
gains (or losses) on the Gold ETF be taxed? Is that a (i) collectible; (ii) share of stock; or even (iii) a currency hedge?

At one point, the classification of gold bars held in an Individual Retirement Account by a custodian was so disputed that the Internal Revenue Service was forced to proactively rule on the matter. ${ }^{90}$ We can even question Green's assertion that the ordinary meaning of the word 'gold' is not open to interpretation. He claims that:

Dworkin is wrong, however, to see a connection between theories of meaning and theories of law ... Let us assume that the interpretive theory of meaning is true of scientific terms like 'gold.' That would mean that the proper standards for using the word 'gold' are those that would result from critical reflection upon our practice of calling things 'gold' ... If such a view is correct, there could be a pre-existing answer to the question of whether something should be called 'gold,' even if there is currently fundamental disagreement about what should be called 'gold.' 91

Yet, that is almost precisely a description of the state of affairs vis-à-vis the meaning of the word 'gold'. The ordinary meaning of the word 'gold' is quite different based on the context in which it is used. It might refer to one particular stick in a box of crayons, to a 14 karat gold necklace, or a 24 karat gold coin. For example, in the purchase of an engagement ring, the distinction between 14 karat gold and 24 karat gold is crucial. By contrast, when an investor sells a Roman-era 'gold' coin (eg, 50\% purity) the United States Department of the Treasury expects a remittance of tax as a collectible. Yet, if the same profit is accrued on the Gold ETF the United States Department of the Treasury typically expects an amount to be reported as capital gain. Accordingly, the term 'gold' is particularly ripe for linguistic analysis and the heuristics of tax law might be consulted to identify the interpretation of the meaning of the word 'gold' in a specific tax context.

\section{E. THE 'MANUFACTURE’ OF FACTUAL INDETERMINACY IMPLIES GAAR}

A committed formalist would consider the idea a general anti-avoidance rule to be an oxymoron because they would not account for the possibility of factual indeterminacy. ${ }^{92}$ Under this view,

\footnotetext{
${ }^{90}$ Internal Revenue Service, Private Letter Ruling 200217059 'With respect to your ruling request, we believe that, based on the information submitted and the representations contained herein, that bullion coins and bullion bars that are assets of IRAs in the physical possession of Company M or its affiliate, Company N, are collectibles within the meaning of Section 408(m)(1) of the Code'.

${ }^{91}$ Green, 'Legal Realism as a Theory of Law' (n 12) 1917.

92 Yovel, "What is Contract Law "About"? Speech Act Theory and a Critique of "Skeletal Promises" (n 76) 959

'A Kelsenian (and Kantian) understanding of normativity is even more removed from SAT: the former approach
} 
all indeterminacy is comprised of legal indeterminacy on application to determinative facts. Furthermore, under Kelsen's approach, posing the possibility of a GAAR implies reference to extra-legal normativity and the pollution of pure legal reasoning. A more moderate position advanced by Prebble is that, by the application of a GAAR, so many extra-legal considerations enter into tax jurisprudence that the Rule of Law is put in jeopardy because tax statutes cannot be interpreted based on what Prebble would consider the ordinary meaning of words. ${ }^{93}$ Indeed, GAARs are now the subject of intense debate in tax circles across Europe after the European Commission recently added an anti-abuse rule for tax avoidance transactions. ${ }^{94}$ Furthermore, the OECD is now considering the addition of a Limitation on Benefits (or anti-abuse) provision, to its model treaty. ${ }^{95}$

However, in the case of manufactured factual indeterminacy the role of the GAAR is more straightforward. ${ }^{96}$ The entry of the 'bad man' into legal practice requires a response, particularly in the taxation context. That is, the law should be seen as incorporating certain principles even without the existence of a statute setting them forth. This was at least the view of Llewellyn:

If, as Karl Llewellyn argued, judicial belief in an implicit obligation of good faith in contractual dealing drove contract decisions in a predictable fashion even before this obligation was included within Article 2 of the UCC, the obligation of good faith was the law according to the prediction theory even before it was so included. ${ }^{97}$

The English common law refers to this as the 'mischief rule'. A common-law GAAR related to tax avoidance is exactly such a mischief rule because the 'bad man' is engaged in

\footnotetext{
regards normativity as a category, a logical primitive analyzable only as such, a "lens" through which phenomena are cogitated, irreducible to linguistic units or mental states and not exhausted by phenomenological explanations'. ${ }^{93}$ See Prebble (n 74).

${ }^{94}$ Council Directive 16435/14 amending Council Directive 2011/96/EU of 30 November 2011 on the Common System of Taxation Applicable in Case of Parent Companies and Subsidiaries of Different Member States, Annex I, 2011 OJ (L345) 8; Bret N Bogenschneider and Romero Tavares, 'The New de minimus Anti-Abuse Rule in the Parent Subsidiary Directive: Validating EU Tax Competition and Corporate Tax Avoidance?' (2015) 43(8) Intertax 484.

95 OECD, 'Preventing the Granting of Treaty Benefits in Inappropriate Circumstances' (Report of September 26, 2014).

${ }^{96}$ See generally Gregory v Helvering, (1935) 293 US 465; Consolidated Edison Co v US, (2009) $90 \mathrm{Fed} \mathrm{Cl} \mathrm{228;}$ Coltec Ind v US, (2004) $63 \mathrm{Fed} \mathrm{Cl} 716$.

${ }^{97}$ Green, 'Legal Realism as a Theory of Law' (n 12) 1935.
} 
mischief, by definition. ${ }^{98}$ In other words, the manufacture of factual indeterminacy by the Holmesian 'bad man' constitutes legal mischief and must be treated as such. ${ }^{99}$

\section{F. CONCLUSION}

Accounting firms are now rapidly disseminating 'manufactured' factual indeterminacy around the world. Insofar as Llewellyn's Bramble Bush operates as the de facto legal rule for tax enforcement (under circumstance of factual indeterminacy), tax professionals are responsible for tax jurisprudence. Lawyers and accountants of professional service firms effectively act as the sheriffs of tax law, particularly since few tax planning decisions are ever formally adjudicated. Accordingly, it is these tax professionals who have the opportunity to apply common standards of good faith to legal practice. ${ }^{100}$

This globalisation of tax jurisprudence falls outside of the Kelsenian formalist's capacity to analyse and explain because it is not derived from any legal norm, nor is it even necessarily driven by lawyers. ${ }^{101}$ It is the general method of tax planning as practiced by accounting firms to manufacture factual indeterminacy and thereby exploit formalism's limitations. ${ }^{102}$ This intentional creation of indeterminacy to avoid taxation is more conducive to the law's corruption than to its purity. The application of a 'soft realism' approach as a legal method takes into account the benefits of formalism in easy cases, and realism in the harder case of factual indeterminacy. A soft realism approach if applied in practice would eliminate the built-in incentive for tax planning designed to 'manufacture' factual indeterminacy by intentional exploitation of a purely formalistic form of interpretation in tax cases.

\footnotetext{
${ }^{98}$ See Schauer, 'Formalism' (n 25) 532 'Somewhat less explicitly, the "mischief rule” of the common law compels the literal language of a rule to yield to the purpose behind a rule when application of the literal language would frustrate the rule's purpose'.

${ }^{99}$ Morgan (n 17) 87 'The taxpayer gets to organize his affairs around the windfall that whistles between the treaty's cracks. With echoes of John Marshall and virtually every other international jurist, tax treaties and their interpretation are situated precariously between the sovereignty of the state and the sovereignty of an overarching law'.

${ }^{100} \mathrm{ibid}$ 'But once it is conceded that national and international law are both positive law, it is obvious that both must be considered as valid simultaneously from the same juristic point of view. For this reason, they must belong to the same system of norms, they must in some way supplement each other'.

${ }^{101}$ ibid 66 'If there is a legal order superior to the national legal orders, it must be international law.'; Somek (n 26) 448 'In exploring the sources of customary international law, Kelsen pointed out that custom - "one ought to do like all the others do" - is all that matters'.

${ }^{102}$ See generally J Peter Pham, 'The Perils of "Consensus": Hans Kelsen and the Legal Philosophy of the United Nations' (2004) 14 Indiana International Comparative Law Review 553.
} 